\title{
Analisis Deskriptif Konsumen dan Mitra Pengemudi pada Jasa Transportasi Online Ride Sharing
}

\author{
Pratama M.G., Wibawa B.M., dan Kunaifi A. \\ Departemen Manajemen Bisnis, Fakultas Bisnis dan Manajemen Teknologi, Institut Teknologi Sepuluh Nopember
} (ITS)

\begin{abstract}
Abstrak-Jasa transportasi online ride sharing mulai dikenalkan di Indonesia sejak tahun 2010 dan menjadi populer di masyarakat pada tahun 2014. Tujuan dari penelitian ini adalah mengidentifikasi karakteristik demografis pada konsumen jasa transportasi online ride sharing. Penelitian ini menggunakan pendekatan survei, deskriptif, konklusif, dan multi cross-sectional. Data dalam penelitian ini didapatkan menggunakan metode survei kuesioner kepada 102 responden pengguna dan 56 responden mitra jasa transportasi online ride sharing di Jabodetabek. Hasil dari penelitian ini adalah karakteristik demografi dan opinion leader pada kategori difusi inovasi pada responden konsumen dan responden mitra.
\end{abstract}

Kata Kunci-Online Ride Sharing, Demografi, Economic Sharing.

\section{PENDAHULUAN}

$\mathrm{P}$ ENGGUNA internet di Indonesia juga mengalami peningkatan setiap tahun. Diperkirakan jumlah pengguna internet di Indonesia pada tahun 2020 nanti mencapai 145 juta jiwa atau sekitar 53 persen dari perkiraan populasi masyarakat Indonesia pada saat itu [1].

Internet menyebabkan berbagai macam perubahan dalam bisnis, salah satunya adalah perubahan pada bisnis jasa transportasi taksi. Saat ini terdapat perluasan jasa transportasi taksi yang dikenal dengan online ride sharing atau jasa transportasi online ride sharing. Jasa transportasi online ride sharing masuk ke Indonesia pada tahun 2010 ditandai dengan terbentuknya Go-Jek. Dengan munculnya inovasi pada industri transportasi, perubahan gaya bertransportasi pun muncul di masyarakat. Dengan bantuan aplikasi smartphone dan internet, konsumen bisa dengan mudah mendapatkan transportasi dengan sangat nyaman.

Terdapat beberapa faktor kunci yang mendukung pertumbuhan industri jasa transportasi ride sharing. Salah satu factor kunci yang mendukung adalah adanya early adopter. Early adopter adalah golongan dalam masyarakat yang menjadi opinion leader dalam penggunaan suatu teknologi [2].

Bila dibandingkan di luar negeri, perkembangan dan penyerapan inovasi jasa layanan ride sharing cenderung lebih lambat. Go-Jek pertama kali mendapatkan pesanan pada 2010, tetapi baru dikenal luas oleh masyarakat setelah meluncurkan aplikasi pada tahun 2014. Faktor difusi inovasi diduga sebagai faktor yang membuat perkembangan Go-Jek di indonesia lambat. Difusi inovasi merupakan sebuah proses dimana inovasi dikomunikasikan melalui berbagai media pada suatu waktu terhadap anggota dari sebuah sistem social [2].

Memasarkan sebuah produk baru adalah salah satu tantangan tersulit yang dihadapi oleh perusahaan [3]. Penerimaan konsumen dan kepuasan konsumen memiliki kontribusi paling besar dalam kesuksesan secara keseluruhan dari sebuah produk baru [4]. Sependapat dengan itu, resistensi konsumen adalah salah satu faktor utama kegagalan pasar dari sebuah inovasi [5]. Resistensi konsumen dipengaruhi oleh seberapa lama waktu yang dibutuhkan untuk mengadopsi sebuah inovasi. Berdasarkan perbedaan waktu dalam mengadopsi sebuah inovasi, konsumen dapat dibagi menjadi beberapa kategori dimana pada setiap kategori memiliki perilaku yang sama terhadap sebuah inovasi [6].

Masyarakat Indonesia masih sangat sulit untuk menerima inovasi baru. Salah satu yang menjadi penghambat dari difusi inovasi adalah lamanya waktu yang dibutuhkan oleh masyarakat sebelum memutuskan untuk menggunakan inovasi dikarenakan pengambilan keputusan tidak dilakukan oleh satu individu itu saja [7]. Banyak masyarakat yang mengadopsi listrik prabayar bukan karena keinginan individu tetapi karena adanya paksaan [8].

\section{TINJAUAN PUSTAKA}

\section{A. Sharing Economy}

Sharing Economy adalah sebuah sistem sosioekonomi yang dibangun berdasarkan sumberdaya manusia, sumberdaya fisik, dan sumberdaya intelektual bersama. Sharing economy adalah sebuah sistem ekonomi berkelanjutan yang terdiri dari 10 aspek yaitu orang-orang, produksi, nilai, distribusi, planet, kekuatan, hukum bersama, komunikasi, budaya, dan masa depan [9].

\section{METODOLOGI PENELITIAN}

\section{A. Jenis Data}

Data primer yaitu data karakteristik demografi responden diambil dengan metode survei dengan kuesioner pada responden yang dianggap mewakili sampel dari populasi penelitian. Data yang diambil adalah data dengan jenis data nominal dan ordinal. Data yang ada lalu diolah secara deskriptif.

\section{B. Pengumpulan Data}

Penelitian dilakukan dengan menggunakan metode survei melalui kuesioner yang disebar secara offline. Populasi dari riset ini adalah seluruh pengguna jasa online ride sharing di Jabodetabek. Peneliti mengambil sampel dari populasi tersebut dengan teknik pengambilan sampel non-probability sampling. Metode yang dipilih adalah convenience sampling, yakni peneliti memiliki kebebasan untuk memilih responden berdasarkan pertimbangan pribadi. Sejumlah 158 kuesioner disebar dari bulan Desember 2016 hingga Januari 2017. Analisis pada penelitian ini adalah analisis deskriptif. 


\section{IV.ANALISIS DAN PEMBAHASAN}

\section{A. Analisis Deskriftif}

Analisis deskriptif demografi dan usage dilakukan untuk mengetahui distribusi dari responden penelitian. Berikut adalah hasil analisis demografi responden pada Tabel 1 dan Tabel 2.

Tabel 1.

Demografi responden Konsumen

\begin{tabular}{|c|c|c|}
\hline Profil & Frekuensi & Persentase $(\%)$ \\
\hline \multicolumn{3}{|l|}{ Jenis kelamin } \\
\hline Pria & 48 & 47,06 \\
\hline \multirow[t]{2}{*}{ Wanita } & 54 & 52,94 \\
\hline & 102 & 100,00 \\
\hline \multicolumn{3}{|l|}{ Usia } \\
\hline $18-24$ & 62 & 60,78 \\
\hline $25-30$ & 20 & 19,61 \\
\hline $31-40$ & 11 & 10,78 \\
\hline \multirow[t]{2}{*}{$>40$} & 9 & 8,82 \\
\hline & 102 & 100,00 \\
\hline \multicolumn{3}{|l|}{ Status pernikahan } \\
\hline Belum menikah & 80 & 78,43 \\
\hline Menikah & 22 & 21,57 \\
\hline \multirow[t]{2}{*}{ Janda/ Duda } & 0 & 0,00 \\
\hline & 102 & 100,00 \\
\hline \multicolumn{3}{|l|}{ Daerah tempat tinggal } \\
\hline Jakarta Utara & 39 & 38,24 \\
\hline Jakarta Pusat & 9 & 8,82 \\
\hline Jakarta Barat & 1 & 0,98 \\
\hline Jakarta Timur & 17 & 16,67 \\
\hline Jakarta Selatan & 8 & 7,84 \\
\hline Jabodetabek non-Jakarta & 28 & 27,45 \\
\hline Total & 102 & 100,00 \\
\hline \multicolumn{3}{|l|}{ Pendapatan per bulan (take home pay) } \\
\hline$<\mathrm{Rp} 2.000 .000$ & 17 & 16,67 \\
\hline Rp2.000.000-Rp3.199.999 & 22 & 21,57 \\
\hline Rp3.200.000-Rp5.000.000 & 35 & 34,31 \\
\hline \multirow[t]{2}{*}{$>$ Rp5.000.000 } & 28 & 27,45 \\
\hline & 102 & 100,00 \\
\hline \multicolumn{3}{|c|}{ Pengeluaran per bulan untuk transportasi online ride sharing } \\
\hline$<\mathrm{Rp} 50.000$ & 33 & 32,35 \\
\hline Rp50.000-Rp100.000 & 41 & 40,20 \\
\hline Rp100.001-Rp200.000 & 12 & 11,76 \\
\hline Rp200.001-Rp500.000 & 13 & 12,75 \\
\hline \multirow[t]{2}{*}{$>$ Rp500.000 } & 3 & 2,94 \\
\hline & 102 & 100,00 \\
\hline \multicolumn{3}{|l|}{ Pendidikan terakhir } \\
\hline SMA/ sederajat & 30 & 29,41 \\
\hline Diploma & 23 & 22,55 \\
\hline Sarjana & 46 & 45,10 \\
\hline Pascasarjana & 2 & 1,96 \\
\hline \multirow[t]{2}{*}{ Lainnya } & 1 & 0,98 \\
\hline & 102 & 100,00 \\
\hline \multicolumn{3}{|l|}{ Pekerjaan } \\
\hline Pegawai negeri sipil & 2 & 1,96 \\
\hline Pegawai swasta & 71 & 69,61 \\
\hline Wiraswasta & 5 & 4,90 \\
\hline TNI/ POLRI & 0 & 0,00 \\
\hline Pelajar/ Mahasiswa & 21 & 20,59 \\
\hline Lainnya & 3 & 2,94 \\
\hline Total & 102 & 100,00 \\
\hline
\end{tabular}

Mayoritas responden dalam penelitian ini adalah wanita. Bila dilihat dari kategori kelompok usia, sebagian besar responden masuk kedalam kategori 18-24 tahun. Sebanyak 34,31 persen responden memiliki pendapatan diatas UMR DKI Jakarta yaitu di rentang 3,2 juta -5 juta rupiah.
Tabel 2.

Demografi Responden Konsumen (lanjutan)

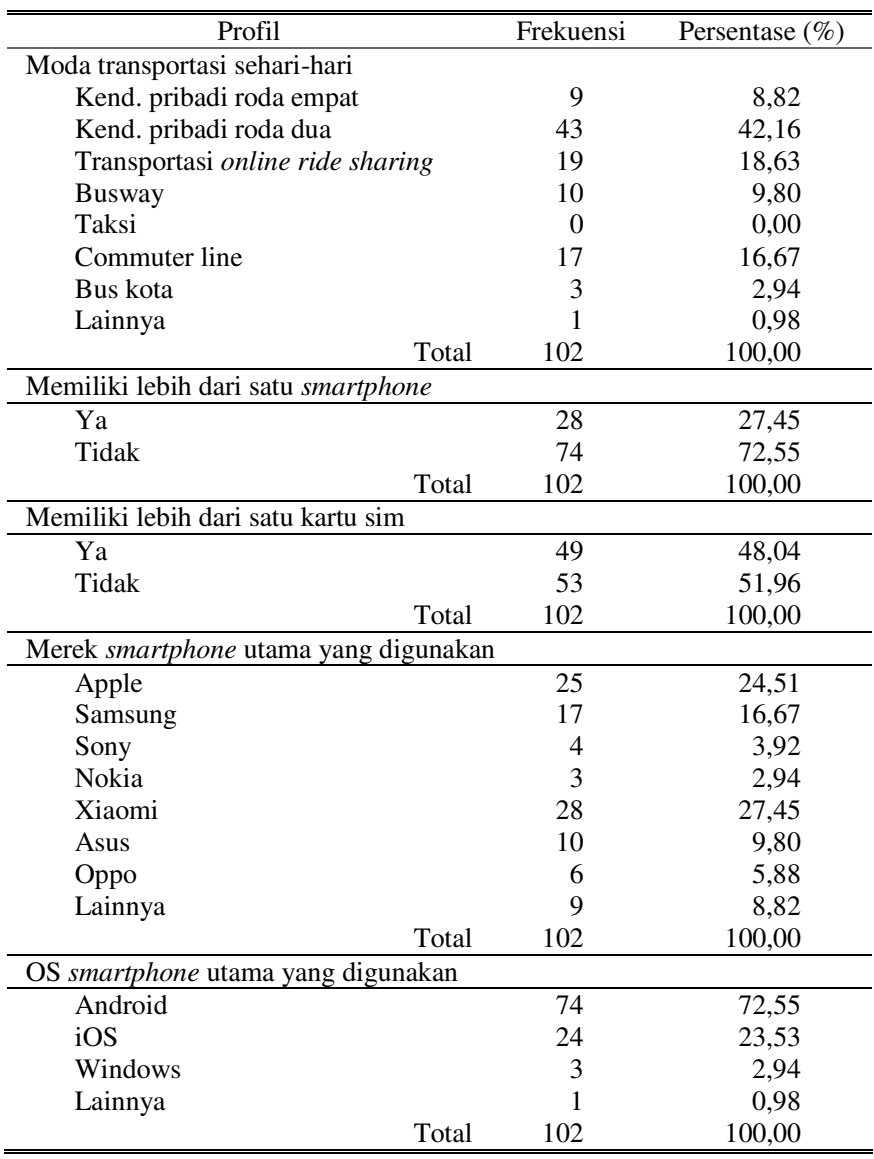

Banyaknya responden dari kalangan menengah disebabkan karena banyak responden konsumen dalam penelitian ini yang bekerja pegawai swasta Pengeluaran yang dibelanjakan responden konsumen untuk jasa transportasi online ride sharing tergolong kecil. Hal ini disebabkan kebutuhan responden terhadap jasa transportasi online ride sharing sangatlah kecil. Mayoritas responden menggunakan kendaraan pribadi dengan jumlah 9 responden yang menggunakan mobil pribadi dan 43 responden yang menggunakan motor pribadi. Kesibukan yang dimiliki responden yang sebagian besar bekerja sebagai pegawai swasta menuntut mereka untuk memiliki mobilitas yang tinggi. Terlebih lagi kemacetan di daerah Jakarta dan tidak nyamannya moda transportasi umum membuat banyak masyarakat Jakarta akhirnya memutuskan untuk membeli kendaraan pribadi.

Selanjutnya analisis deskriptif untuk responden mitra.

Tabel 3. Demografi responden mitra

\begin{tabular}{|c|c|c|c|}
\hline Profil & & Frekuensi & $\begin{array}{c}\text { Persentase } \\
(\%)\end{array}$ \\
\hline \multicolumn{4}{|l|}{ Jenis kelamin } \\
\hline Pria & & 53 & 94,64 \\
\hline Wanita & & 3 & 5,36 \\
\hline & Total & 56 & 100,00 \\
\hline
\end{tabular}


Tabel 4.

Tabel 5.

Demografi responden mitra (lanjutan)

\begin{tabular}{|c|c|c|c|}
\hline Profil & & Frekuensi & Persentase (\%) \\
\hline \multicolumn{4}{|l|}{ Usia } \\
\hline $18-24$ & & 6 & 10,71 \\
\hline $25-30$ & & 15 & 26,79 \\
\hline $31-40$ & & 22 & 39,29 \\
\hline \multirow{2}{*}{$>40$} & & 13 & 23,21 \\
\hline & Total & 56 & 100,00 \\
\hline \multicolumn{4}{|l|}{ Status pernikahan } \\
\hline Belum menikah & & 12 & 21,43 \\
\hline Menikah & & 44 & 78,57 \\
\hline \multirow[t]{2}{*}{ Janda/ Duda } & & 0 & 0,00 \\
\hline & Total & 56 & 100,00 \\
\hline \multicolumn{4}{|l|}{ Daerah tempat tinggal } \\
\hline Jakarta Utara & & 7 & 12,50 \\
\hline Jakarta Pusat & & 4 & 7,14 \\
\hline Jakarta Barat & & 3 & 5,36 \\
\hline Jakarta Timur & & 28 & 50,00 \\
\hline Jakarta Selatan & & 7 & 12,50 \\
\hline \multirow[t]{2}{*}{ Jabodetabek non-Jakarta } & & 7 & 12,50 \\
\hline & Total & 56 & 100,00 \\
\hline \multicolumn{4}{|c|}{ Pendapatan per bulan dari transportasi online ride sharing } \\
\hline$<\mathrm{Rp} 2.000 .000$ & & 16 & 28,57 \\
\hline Rp2.000.000-Rp3.199.999 & & 15 & 26,79 \\
\hline Rp3.200.000-Rp5.000.000 & & 16 & 28,57 \\
\hline \multirow[t]{2}{*}{$>$ Rp5.000.000 } & & 9 & 16,07 \\
\hline & Total & 56 & 100,00 \\
\hline \multicolumn{4}{|c|}{ Pekerjaan selain mitra pengemudi transportasi online ride sharing } \\
\hline Pegawai negeri sipil & & 0 & 0,00 \\
\hline Pegawai swasta & & 19 & 33,93 \\
\hline Wiraswasta & & 6 & 10,71 \\
\hline Pelajar/ Mahasiswa & & 5 & 8,93 \\
\hline Tidak ada & & 25 & 44,64 \\
\hline Lainnya & & 1 & 1,79 \\
\hline & Total & 56 & 100,00 \\
\hline \multicolumn{4}{|c|}{ Pekerjaan sebelum mitra online ride sharing } \\
\hline Sama dengan pekerjaan saat ini & & 25 & 44,64 \\
\hline Ojek pangkalan & & 3 & 5,36 \\
\hline Tidak ada & & 15 & 26,79 \\
\hline \multirow[t]{2}{*}{ Lainnya } & & 13 & 23,21 \\
\hline & Total & 56 & 100,00 \\
\hline \multicolumn{4}{|l|}{ Pengeluaran per bulan } \\
\hline$<\operatorname{Rp} 2.000 .000$ & & 14 & 25,00 \\
\hline Rp2.000.000-Rp3.200.000 & & 17 & 30,36 \\
\hline Rp3.200.001-Rp5.000.000 & & 16 & 28,57 \\
\hline \multirow[t]{2}{*}{$>$ Rp5.000.000 } & & 9 & 16,07 \\
\hline & Total & 56 & 100,00 \\
\hline \multicolumn{4}{|l|}{ Pendidikan terakhir } \\
\hline SMP atau Sederajat & & 5 & 8,93 \\
\hline SMA atau Sederajat & & 37 & 66,07 \\
\hline Diploma, Sarjana, Pascasarjana & & 12 & 21,43 \\
\hline \multirow[t]{2}{*}{ Lainnya } & & 2 & 3,57 \\
\hline & Total & 56 & 100,00 \\
\hline \multicolumn{4}{|l|}{ Lama waktu menjadi mitra per hari } \\
\hline$<2 \mathrm{Jam}$ & & 0 & 0,00 \\
\hline 2-5 Jam & & 16 & 28,57 \\
\hline 5-10 Jam & & 24 & 42,86 \\
\hline \multirow[t]{2}{*}{$>10 \mathrm{Jam}$} & & 16 & 28,57 \\
\hline & Total & 56 & 100,00 \\
\hline
\end{tabular}

Bila dilihat, responden mitra didominasi oleh oleh lakilaki karena sebagian besar responden dalam penelitian ini adah mitra pengendara kendaraan roda dua atau motor. Selain itu hal ini terjadi karena pekerjaan ini menuntut untuk banyak menghabiskan waktu di jalan. Sebagian besar responden yang menjadi mitra adalah responden yang berada pada rentang usia 31-39 tahun. Pada usia ini beban dan tanggung jawab ekonomi yang ada semakin besar.

Mayoritas responden mitra dalam penelitian ini sudah menikah. Kebanyakan dari responden berada pada kelompok yang mendapatkan pendapatan sebesar Rp3.200.000-Rp5.000.000 per bulan, walaupun perbedaannya dengan kelompok ekonomi lain tidak terlalu jauh.

\begin{tabular}{|c|c|c|c|}
\hline \multicolumn{2}{|l|}{ Profil } & Frekuensi & Persentase (\%) \\
\hline \multicolumn{4}{|c|}{ Merek kendaraan yang digunakan } \\
\hline Mobil-Honda & & 1 & 1,79 \\
\hline Mobil-Toyota & & 3 & 5,36 \\
\hline Mobil-Daihatsu & & 1 & 1,79 \\
\hline Mobil-Datsun & & 1 & 1,79 \\
\hline Mobil-Nissan & & 0 & 0,00 \\
\hline Motor-Honda & & 40 & 71,43 \\
\hline Motor-Yamaha & & 5 & 8,93 \\
\hline Motor-Suzuki & & 0 & 0,00 \\
\hline \multirow[t]{2}{*}{ Lainnya } & & 5 & 8,93 \\
\hline & Total & 56 & 91,07 \\
\hline \multicolumn{4}{|l|}{ Tipe kendaraan } \\
\hline Mobil-Minivan & & 5 & 8,93 \\
\hline Mobil-Hatchback & & 3 & 5,36 \\
\hline Mobil-Sedan & & 0 & 0,00 \\
\hline Motor-Road bike & & 3 & 5,36 \\
\hline Motor-Bebek & & 10 & 17,86 \\
\hline Motor matik & & 35 & 62,50 \\
\hline Lainnya & & 0 & 0,00 \\
\hline & Total & 56 & 100,00 \\
\hline
\end{tabular}

Salah satu yang menyebabkan perbedaan ini adalah lamanya waktu yang mereka berikan untuk menjadi mitra dalam satu hari. Sebagian besar responden dalam penelitian ini menjadikan mitra transportasi online ride sharing sebagai pekerjaan utama dan tidak memiliki pekerjaan lain. Kebanyakan responden sudah merasa nyaman dengan pekerjaan sebagai mitra pengemudi disebabkan fleksibilitas dalam mengatur waktu. Dari 56 data responden yang terkumpul, mayoritas responden menjawab bahwa pekerjaan mereka sebelum menjadi mitra transportasi online ride sharing adalah sama dengan pekerjaan mereka saat ini. Dari temuan ini dapat dilihat bahwa sebagian besar mitra bukan mereka yang berasal dari profesi ojek pangkalan. Sebagian besar responden memiliki latar belakang pendidikan SMA dan sederajat. Mayoritas responden menjawab bahwa mereka menghabiskan 5-10 jam setiap hari. Responden dalam penelitian ini didominasi oleh responden mitra roda dua. Merek Honda menjadi merek mayoritas dari kendaraan yang digunakan oleh mitra pengemudi. Motor matik masih menjadi produk andalan bagi mitra pengemudi.

\section{KESIMPULAN}

Secara umum, masing-masing responden konsumen dan mitra memiliki karakteristik demografi yang berbeda. Pada responden konsumen dapat kita lihat bahwa kebanyakan dari mereka adalah wanita dengan rentang usia muda dan memiliki latar belakang pendidikan sarjana. Sedangkan pada responden mitra, kebanyakan dari mereka adalah laki laki dengan rentang usia dewasa dan memiliki latar belakang pendidikan SMA.

Selain itu ada beberapa temuan seperti misalnya pada responden konsumen kebanyakan dari mereka sudah memiliki kendaraan pribadi sehingga akan mempengaruhi kepada keinginan untuk menggunakan jasa online ride sharing. Lalu untuk responden mitra ditemukan bahwa kebanyakan dari mereka yang menjadi mitra bukan mereka yang sebelumnya berprofesi sebagai ojek pangkalan. Hal ini menunjukkan bahwa sebenarnya niat awal penyedia jasa transportasi online ride sharing untuk merangkul kalangan ojek konvensional belum tepat sasaran. 


\section{DAFTAR PUSTAKA}

[1] Das and et al, "Unlocking Indonesia's Digital Opportunity," McKinsey Indonesia, $2016 . \quad$ [Online]. Available: http://www.mckinsey.com/global-locations/asia/indonesia/en/latestthinking.

[2] E. M. Rogers, Diffusion of Innovations. New York: The Free Press, 1983.

[3] D. Lunsford and M. Burnett, "Marketing product innovations to the elderly: Understanding the barriers to adoption," J. Consum. Mark., pp. 53-63, 1992.

[4] X. Huang, G. Soutar, and A. Brown, "Measuring New Product Success: An Empirical investigation of Australian SMEs," Ind. Mark. Manag., pp. 117-123, 2004.

[5] S. Ram and J. Sheth, "Consumer Resistance to Innovations: The
Marketing Problem and its Solutions," J. Consum. Mark., pp. 5-14, 1989.

[6] Martinez and et al, "The Acceptance and Diffusion of New Consumer Durables: Differences between first and last adopters," J. Consum. Mark., pp. 323-342, 1989.

[7] S. Y. Pradhana, "Difusi Dan Adopsi Inovasi Program Keluarga Berencana 'Dua Anak Lebih Baik' Dalam Mengendalikan Pertumbuhan Penduduk," Surakarta, 2013.

[8] R. Karlina, "Studi Difusi Inovasi Program Layanan Listrik Prabayar PT. PLN (PERSERO) APJ Surakarta Terhadap Adopsi Inovasi pada Masyarakat Surakarta," Surakarta, 2011.

[9] B. Matofska, "What is The Sharing Economy," 2016. [Online]. Available: http://thepeoplewhoshare.com/blog/what-is-the-sharingeconomy. 